agricultural research assumed a pipeline of technology from lab to farm. In future, the farmer should be seen as a co-producer of research, not a recipient of handeddown technology. China is fostering this approach. Juma gives a good illustration of the boom in vegetable production in China's Shandong province, where local government has encouraged a range of businesses and market development.

With its climate changing and population growing, Africa will have to produce food under greater environmental pressure. He argues that agriculture needs to shift towards more sustainable farming patterns, which are also more knowledgeintensive. This will require governments and societies to address the deficit in training and access to education, particularly for women, who are the backbone of food production in many African farming communities. For example, the non-governmental Uganda Rural Development and Training programme teaches farming methods using a curriculum that focuses on building strong female agricultural leaders.

Weak infrastructure and scarce land and water may be harder to overcome than Juma suggests. A few African governments recognize the potential of agriculture to drive economic growth and reduce poverty, but there is still a long way to go. Climate-change impacts could be hugely damaging unless urgent work is done to construct resilient local and national systems. A focus on the benefits of global markets, inward investment and modern technology needs to be balanced by consideration for who gains and who loses.

Concerns are already being raised by farmers' associations about large-scale investment in agricultural land, in 'landgrab' deals negotiated by few people. In Mali, farmers want a moratorium on large land allocations, and have issued a call to remind the government that land, water, forests and natural resources constitute national assets for all citizens. Other investment models, such as contract farming or joint ventures with local farmers, should be considered. Transparency is also needed to ensure that investors undertake their contractual obligations and do not engage in speculation.

Like Juma, I see the glass as half full, but there are many challenges ahead. Nevertheless, The New Harvest reminds us that by working with farmers, nongovernmental organizations, government and business, science has the potential to transform Africa's food security.

Camilla Toulmin is director of the International Institute for Environment and Development, London, UK. e-mail:camilla.toulmin@iied.org

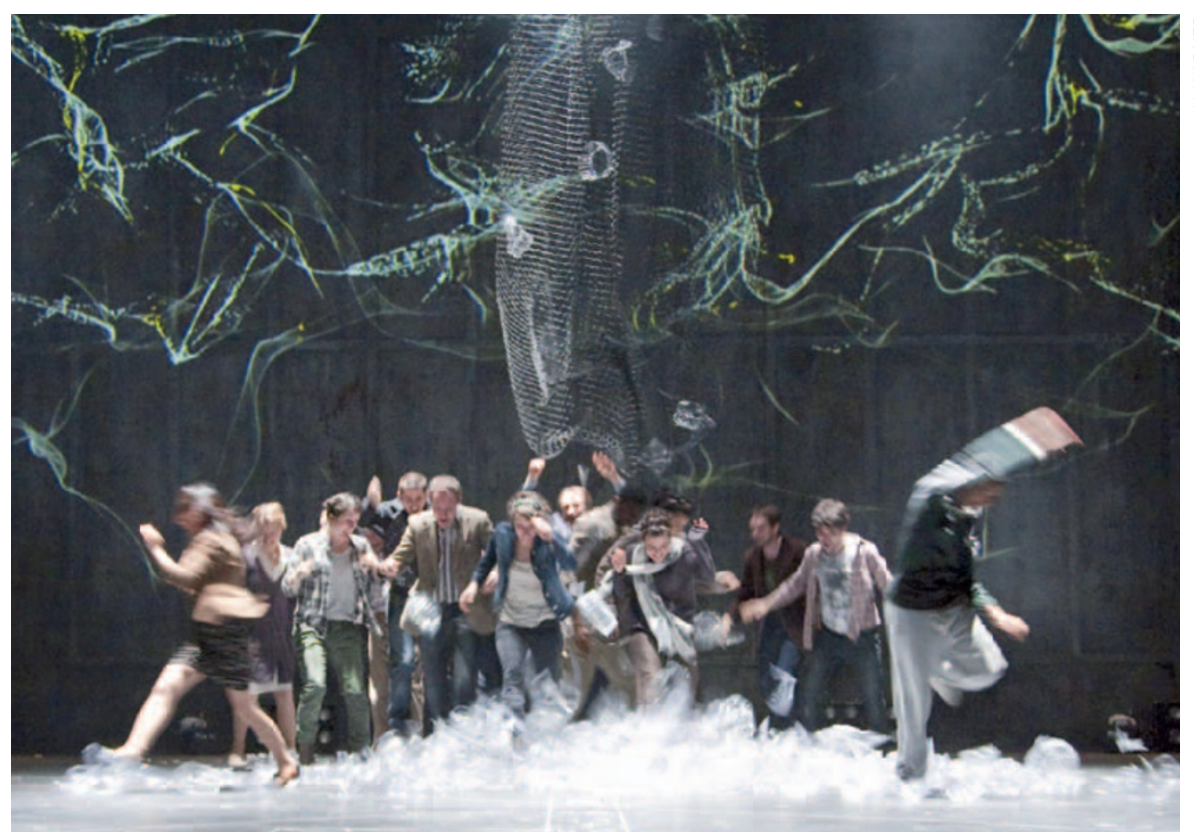

Greenland gives an alarming assessment of climate change in a production as complex as the topic itself.

THEATRE

\title{
Poles apart on climate
}

\section{Two contrasting plays highlight the difficulties of putting global warming on stage, finds Kerri Smith.}

$\mathrm{F}$ Terocious debate has polarized the issue of climate change - and two plays currently running in London reveal many facets of those arguments. Greenland is a rational but disjointed assessment of how urgent and alarming our predicament is, whereas The Heretic is an entertaining family drama with a climate sceptic as the protagonist.

Greenland, at the National Theatre, is a production almost as complex and unwieldy as climate change itself. It weaves together several narratives: a student-teacher becomes a green activist; a birdwatcher witnesses habitat change in the Arctic; a couple argue over their individual contributions to global warming. These unfolding tales share the stage with falling rain and a remarkably life-like model of a polar bear.

The most engaging scenes involve the play's climate modeller, Ray, and a government official, Phoebe, sent to gather data ahead of the December 2009 climate negotiations in Copenhagen. She arrives at the lab after he has worked all night on his model; he is reticent to let her see his work before it has been peer reviewed. When they get to Copenhagen, we are given a sense of the convoluted processes involved in drafting an international policy agreement when a dozen weighty volumes fall
Greenland

MOIRA BUFFINI, MATT CHARMAN, PENELOPE

SKINNER AND JACK THORNE

National Theatre, London. Until 2 April 2011.

\section{The Heretic}

RICHARD BEAN

Royal Court Theatre, London. Until 19 March 2011.

from the ceiling and land with a thud.

But the multitude of characters and jumbled storylines make this play difficult to follow. Laced with statistics and quotes, it feels at times like a lecture. Greenland's four writers - Moira Buffini, Matt Charman, Penelope Skinner and Jack Thorne - spent months researching the topic by interviewing experts, activists and journalists. The team hoped to convey the complexity of the issue, says the play's artistic director, Ben Power. "We're trying to explore the feeling of powerlessness," he adds. What they actually depict, in shoehorning all their research onto the stage, is confusion.

Richard Bean's The Heretic is easier to watch, with its linear storyline, entertaining characters and laughout-loud dialogue. But its factual errors will infuriate some scientists.

The play centres on

DNATURE.COM Brian Wynne's review of Merchants of Doubt. go.nature.com/tcsjbk 
fictitious professor Diane Cassell, who studies sea-level change in the Maldives. Her data suggest that there is no rise - putting her at odds with her department and making her a target for death threats from an environmental activist group. She infuriates her colleagues even further when she defends her views on a television show hosted by BBC Newsnight presenter Jeremy Paxman — playing himself in a pre-recorded video cameo leading to a dramatic turn of events.

Cassell also tutors a student with strong environmentalist leanings and helps her own daughter, a Greenpeace member, to battle anorexia. One section draws on the e-mail hacking controversy of November 2009 at the University of East Anglia, UK. Cassell's student hacks into another university's mainframe and discovers e-mails in which the author was keen to 'bury the downturn' - a reference to "hide the decline", a phrase in the real hacked e-mails that was seized upon by climate sceptics.

The problem with The Heretic is that although the 'science' presented is sloppy in places, its mouthpiece, Cassell, is likeable, witty and compelling - perhaps enough to convince the audience that the science is sound. Cassell argues, for instance, that the research on sea levels that went into reports from the Intergovernmental Panel on Climate Change "used a single tide gauge", rather than the many records that climate scientists actually collected. Interviewed after the play, environmental economist Dimitri Zenghelis of the London School of Economics, who consulted on Greenland, voiced concerns about the misinformation that Cassell's character helps to propagate.

Both plays do a good job of portraying their scientific protagonists as people. In Greenland, climate scientist Ray worries whether it is irresponsible to start a family given future climate risks. Cassell in The Heretic grapples with family and romantic dramas as well as her scientific dilemma. Zenghelis says one helpful aspect of The Heretic is that Cassell's character identifies "the problem of objective scientists without an agenda struggling to be heard". But in the real world, it is not the sceptics who have trouble getting their message out: "[The Heretic] got things the wrong way around," he says.

On the evidence of these two plays, climate science and theatre do not seem to be natural bedfellows. But like the Iraq War or the Enron financial scandal (both subjects of recent plays), complex topics that affect everyone should be dramatized. They just need to be accurate as well as entertaining. "People said to us, 'For God's sake make it an interesting play! Don't lecture us"' Power admits of Greenland. In the end, The Heretic meets this target. Greenland falls short.

\section{Books in brief}

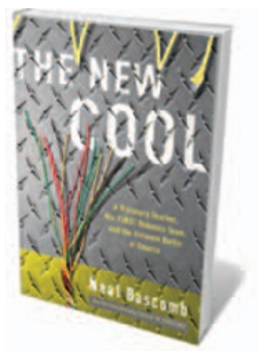

The New Cool: A Visionary Teacher, His FIRST Robotics Team, and the Ultimate Battle of Smarts

Neal Bascomb Crown 352 pp. \$25 (2011)

Robot-building competitions are 'the new cool' in high schools across the United States. Writer Neal Bascomb follows a team of California teenagers and their inspirational physics teacher as they try to win the coveted FIRST (For Inspiration and Recognition of Science and Technology) contest, a nationwide annual project instigated 22 years ago by inventor Dean Kamen. In relating the team's travails, Bascomb shows how children are enthused by hands-on approaches to science and technology.

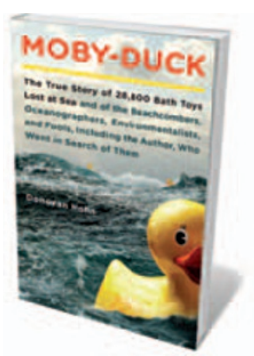

Moby-Duck: The True Story of 28,800 Bath Toys Lost at Sea and of the Beachcombers, Oceanographers, Environmentalists, and Fools, Including the Author, Who Went in Search of Them Donovan Hohn VIKING 416 pp. \$27.95 (2011)

After hearing about thousands of plastic toys washed up on Alaskan shores after the loss of a container from a Chinese ship, journalist Donovan Hohn set out to learn about ocean currents. Retracing the journey of the plastic ducks, frogs and turtles across the Pacific, he reveals how floating markers have been used to map the circulation of the seas. And he questions the globalized economic system that sends cheap novelty products on such odysseys in the first place.

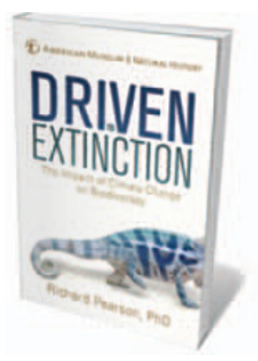

Driven to Extinction: The Impact of Climate Change on Biodiversity Richard Pearson STERLING 264 pp. \$22.95 (2011)

Global warming will result in winners and losers among species, explains Richard Pearson, a biogeographer at the American Museum of Natural History in New York. Offering a balanced assessment of case studies of animals and ecosystems that are already affected by environmental degradation — such as Madagascan geckos, coral reefs and polar bears - he relates how climate change will sever links between organisms. This will lead to inevitable extinctions, he admits. But new niches will emerge in which other species might flourish.

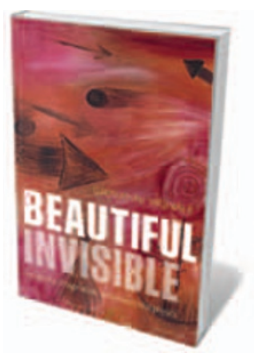

The Beautiful Invisible: Creativity, Imagination, and Theoretical Physics

Giovanni Vignale OXFORD UNIVERSITY PRESS 320 pp. \$34.95 (2011) Physics is much more than just dry mathematics, argues physicist Giovanni Vignale. Its abstract concepts, such as energy and atoms, are products of the imagination that call for a creative approach, and are best viewed as cultural hand-me-downs that have developed from philosophical ideas throughout the ages. In his thoughtful and wide-ranging book, Vignale explores the esoteric side of the discipline, which he sees as "the military academy of liberal arts" owing to its mix of rigour and creativity.

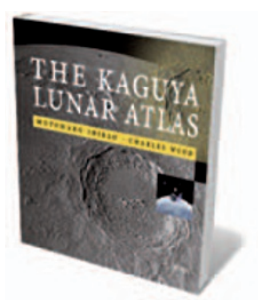

The Kaguya Lunar Atlas: The Moon in High Resolution

Motomaro Shirao and Charles A. Wood SPRINGER 174 pp. \$39.95 (2011)

Lunar landscapes take on a new realism in this atlas of photographs taken by the high-definition television camera aboard the Kaguya (SELENE) spacecraft, operated by the Japanese space agency JAXA. The oblique views, snapped by the low-flying probe from just 100 kilometres above the Moon's surface, show the terrain as it would be seen by astronauts descending to its surface, rather than the vertical views presented by other satellites.

Kerri Smith edits Nature's podcasts. 